\title{
CERPEN SURAU KARYA KHAIRUL JASMI: SUATU ANALISIS SEMIOTIK
}

\section{(A SHORT STORY "SURAU" BY KHAIRUL JASMI: A SEMIOTIC ANALYSIS)}

\author{
Agus Yulianto \\ Balai Bahasa Provinsi Kaimantan Selatan \\ Jalan A. Yani, Km 32, 2 Loktabat, Banjarbaru, Kalimantan Selatan, Indonesia \\ Pos-el: agusb.indo@gmail.com
}

Diterima: 25 Mei 2015 Direvisi: ...Disetujui: ...

\begin{abstract}
Abstracs
Short story is one of literary work in the form of prose. To make a literary work the writer sometimes takes the idea and way of thinking from the changing of it society. Those changing sometimes consist of certain simbols. That's why, to understand a literary work we have to analyze it. One of them is by using semiotic approach. This study analysis simbols which are found in "Surau" short story by Khairul Jasmi and the meaning in it. In this study, the data are simbols in "Surau" short story by Khairul Jasmi and the meaning bounded. The results of the this study show twentythree symbols with their meaning. One of them is the mosque which disapeared 22 years ago is a simbol of religious life in Mr. Karimun.
\end{abstract}

Key Words: Short story, analysis, semiotic

Abstrak

Cerita pendek adalah salah satu karya sastra yang berbentuk prosa. Untuk membuat sebuah karya sastra, penulis kadang-kadang mengambil ide dan cara berfikir dari perubahan di masyarakat. Perubahan tersebut kadang-kadang terdiri dari simbol-simbol tertentu. Oleh karena itu, untuk memahami sebuah karya sastra, kita harus menganalisanya. Salah satu alat yang dipakai untuk menganalisis adalah dengan menggunakan pendekatan semiotika. Penelitian ini menganalisis simbol yang ditemukan di cerita pendek "Surau" karya Khairul Jazmi dan makna yang terkandung di dalamnya. Dalam penelitian ini, data yang dianalisis adalah simbol di cerita pendek "Surau" karya Khairul Jazmi baru kemudian makna yang dikandungnya. Hasil penelitian menemukan 23 simbol yang diberikan makna juga. Salah satu dari simbol tersebut adalah masjid yang hilang 22 tahun yang lalu yang merupakan simbol religius dalam kehidupan Pak Karimun.

Kata kunci: cerita pendek, analisis, semiotika

\section{Pendahuluan}

Karya sastra merupakan ekspresi pengalaman manusia secara menyeluruh tentang hidup dan kehidupan atau tentang manusia dan kemanusiaan. Kelahiran karya sastra diilhami oleh berbagai kondisi manusiawi: persaudaraan, penderitaan, citacita, perjuangan, dan sebagainya. Realitas kehidupan, lengkap dengan berbagai sisi yang terkandung di dalamnya direkam oleh pengarang dan diolah sedemikian rupa kemudian diekspresikan dalam gaya dan bentuk yang khas (Nico, 1993:1). Ekspresi manusia dalam kesusastraan itu sendiri dapat berwujud puisi, prosa maupun drama.

Cerita pendek sebagai bagian dari prosa merupakan salah satu bentuk karya sastra yang telah diakui keberadaannya disamping novel, puisi, maupun drama. Sesuai dengan nama danwujudnya, cerita pendek memang relatif tidak terlalu panjang dan dapat dibaca dalam waktu singkat. 
Namun, perwujudan yang relatif pendek dengan penceritaan yang singkat tidak berarti bahwa cerita pendek kurang bernilai literer. Walaupun wujudnya relatif pendek, cerita pendek menampilkan persoalan manusia dengan liku-liku kehidupannya. Oleh sebab itu, dengan mengakrabi cerita pendek, kita dapat memetik manfaat dari pesan-pesan yang dikandungnya.

Selanjutnya, sebuah karya sastra termasuk cerpen adalah artefak (benda mati) yang baru mempunyai makna dan menjadi objek estetik jika diberi arti oleh manusia pembaca sebagaimana artefak peninggalan manusia purba mempunyai arti bila diberi makna oleh seorang arkeolog (Teeuw, 1984:191). Dengan demikian, sebuah karya sastra tidak akan bermakna atau bernilai jika tidak diberikan atau diungkapkan oleh pembaca.

Salah satu peranti analisis sastra yang dapat digunakan untuk mengungkap karya sastra adalah semiotik. Telaah karya sastra dengan menggunakan pendekatan semiotik tidak dapat dipisahkan dengan analisis struktural karena sama-sama beranggapan bahwa karya sastra sebagai sebuah struktur (sistem) tanda-tanda yang bermakna (Pradopo, 1987:117--124). Karya sastra merupakan struktur yang kompleks. Untuk memahaminya karya sastra tersebut harus dianalisis (Hill, 1966:6). Dalam menganalisisnya, karya sastra diuraikan lengkap dengan unsur-unsur pembentuknya karena dengan cara seperti itulah makna keseluruhan karya sastra bisa diungkapkan. Hal itu mengingat karya sastra sebagai sebuah kesusastraan yang utuhyang maknanya hanya dapat dipahami jika unsurunsur pembentuknya diketahui dan hubungan antara unsur-unsur pembentuk tersebut dalam keseluruhan juga dimaklumi (Hawkes, 1978:16). Unsur-unsur atau bagian-bagian karya sastra sebagai bahagian dari struktur tidak mempunyai makna sendiri, tetapi makna ditentukan oleh hubungannya dengan unsur-unsur atau bagian-bagian lainnya dengan keseluruhannya (Hawkes, 1978:17--18).

Salah satu karya sastra yang menarik untuk dianalisis secara semiotik adalah cerpen Surau karya Khairul Jasmi. Cerpen ini penuh dengan simbol-simbol yang dengan sendirinya menarik untuk dianalisis secara semiotik. Hasil penelitian ini diharapkan dapat memberikan sumbangan pemikiran bagi pembinaan dan pengembangan sastra, peningkatan pengajaran apresiasi sastra khususnya cerpen, karena kegiatan penelitian seperti ini sangat penting pula artinya bagi para penyusun buku sastra untuk sekolah tingkat lanjutan.

Deskripsi dan analisis cerpen Surau karya Khairul Jasmi melalui pendekatan semiotik ini dapat disumbangkan untuk memperkaya pemahaman terhadap cerpencerpen sejenis. Apabila demikian dengan sendirinya cerpen ini ada relevansinya dengan upaya pengembangan teori sastra yang ada.

Menurut sepengetahuan peneliti sejauh ini analisis semiotik terhadap cerpen Surau karya Khairul Jasmi belum pernah dilakukan. Hal inilah yang menyebabkan peneliti tertarik untuk menganalisis cerpen tersebut.

Sesuai dengan judul penelitian ini, yaitu Cerpen Surau karya Khairul Jasmi: Suatu Analisis Semiotik, maka objek penelitian ini bertitik pangkal pada analisis semiotik. Seperti dikatakan oleh Zaimar (1991) interpretasi terhadap karya sastra masuk dalam lingkup makna dan makna merupakan lingkup bidang semiotik. Berdasarkan hal tersebut maka masalah dalam penelitian ini dapat dirumuskan dalam bentuk pertanyaan berikut: Makna apa yang terkandung dalam simbol-simbol yang terdapat dalam cerpen Surau karya Khairul Jasmi tersebut. 
Penelitian tentang cerpen Surau ini mempunyai dua tujuan, yaitu tujuan umum dan khusus. Tujuan umum penelitian ini adalah untuk ikut memberi sumbangan pada studi sastra terutama mengenai analisis semiotik. Ada pun secara khusus penelitian ini untuk mengungkap dan mengeksplisitkan makna yang terkandung dalam cerpen Surau karya Khairul Jasmi.

Penelitian ini juga diharapkan dapat bermanfaat bagi masyarakat pernbaca. Penelitian ini diharapkan dapat membantu masyarakat pembaca dalam memahami cerpen-cerpen sejenis khususnya dan umumnya menambah wawasan apresiasi sastra.

\section{Kerangka Teori}

Cerpen singkatan dari cerita pendek. Cerpen merupakan salah satu karya sastra berbentuk prosa. Menurut Husnan, dkk (1998:81) prosa adalah karangan yang berbentuk prosa, artinya tidak terikat oleh aturan tertentu. Menurut Surana (1982:27) bahwa cerpen adalah hasil sastra yang menceritakan suatu (sejemput) kejadian dalam kehidupan pelakunya. Sejalan dengan itu, Hoerip dalam Semi (1988:34) menyatakan bahwa cerita pendek adalah karakter yang dijabarkan lewat rentetan kejadian daripada kejadian-kejadian itu sendiri satu persatu. Apa yang terjadi di dalamnya lazim merupakan suatu pengalaman atau penjelajahan dan reaksi mental itulah yang pada hakikatnya disebut cerpen.

Rasidi (1959:ix) memberi batasan bahwa cerpen adalah cerita yang pendek dan merupakan suatu kebulatan ide. Dalam kesingkatan dan kepadatannya itu, sebuah cerpen adalah lengkap, bulat, dan singkat. Semua bagian dari sebuah cerpen mesti terikat pada suatu kesatuan jiwa: pendek, padat, dan lengkap.

Selain itu, Sedgwick dalam Tarigan (1988:176) menyatakan bahwa cerpen adalah penyajian suatu keadaan tersendiri atau suatu kelompok keadaan yang memberikan kesan yang tunggal pada jiwa pembaca.

Dari pendapat para penulis di atas dapat disimpulkan bahwa pengertian cerpen adalah cerita pendek yang singkat dan padat yang membahas ceritanya terpusat pada suatu peristiwa pokok dan memusatkan diri pada satu tokoh.dalarn satu situasi sehinga merupakan suatu kebulatan ide yang dapat memberikan kesan tunggal pada jiwa pembacanya.

Pendekatan (approach) adalah prinsip dasar (basic principle) yang menjadi acuan dalam melakukan suatu pengkajian yang ilmiah.Semiotik merupakan salah satu pendekatan yang sedang diminati oleh para ahli dewasa ini, tidak terkecuali para peminat sastra di Indonesia.

Semiotik adalah ilmu tanda; istilah tersebut berasal dari kata Yunani semieon yang berarti "tanda". Tanda terdapat di mana-mana: kata adalah tanda, demikian pula gerak isyarat, lampu lalu lintas, bendera, dan sebagainya.

Ilmu semiotik menganggap bahwa fenomena sosial/masyarakat dan kebudayaan itu merupakan tanda-tanda. Semiotik mempelajari sistem-sistem, aturan-aturan, konvensi-konvensi yang memungkinkan tanda-tanda tersebut mempunyai arti. Dalam bidang kritik sastra, penelitian semiotik meliputi analisis sastra sebagai sebuah penggunaan bahasa yang bergantung pada (sifat-sifat) yang menyebabkan bermacammacam cara (modus) wacana mempunyai makna (Preminger, dkk. dalam Pradopo, 2002: 67-68).

Tanda mempunyai dua aspek yaitu penanda (signifier) dan petanda (signified). Penanda adalah bentuk formalnya yang menandai sesuatu yang disebut petanda, sedangkan petanda adalah sesuatu yang ditandai oleh petanda itu, yaitu artinya. Sebagai contoh, kata "ibu" merupakan tanda 
berupa satuan bunyi yang menandai arti "orang yang melahirkan kita" (Pradopo, 1995:120). Karya sastra merupakan struktur tanda-tanda yang bermakna. Karya sastra itu karya seni yang bermedium bahasa. Bahasa sebagai bahan sastra sudah merupakan sistem tanda (semiotik) tingkat pertama dan mempunyai konvensi sendiri yang menyebabkannya mempunyai arti. Sebagai bahan karya sastra, bahasa disesuaikan dengan konvensi sastra, bahasa menjadi sistem tanda baru, yaitu makna sastra (significance). Jika dipandang dari konvensi bahasa, konvensi sastra itu adalah konvensi "tambahan" kepada konvensi sastra (Pradopo, 1991). Dengan mengutip Preminger, dijelaskan oleh Pradopo lebih lanjut bahwa studi sastra yang bersifat semiotik itu adalah usaha menganalisis karya sastra sebagai suatu sistem tandatanda dan menentukan konvensi apa yang memungkinkan karya sastra mempunyai makna. Dengan melihat variasi-variasi di dalam struktur karya sastra atau hubungan dalam antarunsurnya, akan dihasilkan bermacam-macam makna.

Untuk menemukan makna yang dikandung dalam simbol-simbol yang terdapat dalam tiap-tiap cerita rakyat terlebih dahulu dibuat urutan tekstual ceritanya. Kemudian, dilanjutkan pada analisis makna yang dikandung dalam simbol-simbol yang terdapat dalam cerita dengan menempatkan karya pada konteksnya.

\section{Metode Penelitian}

Metode yang digunakan dalam penelitian ini adalah metode deskriptif dengan pendekatan stuktural semiotik. Maksudnya, penelitian ini dilakukan seobjektif mungkin berdasarkan fakta yang ada dengan pengkajian tanda (signifiant) dan makna (signifie).

Teknik penelitian dilakukan dengan analisis cerita (teks). Cerita itu dianalisis dari segi strukturnya. Analisis dimulai dengan menentukan urutan alur (sinopsis) Setelah struktur cerita analisis, barulah cerita dianalisis secara semiotik dengan menceritakan kembali jalan cerita sampai ditemukan teks cerita yang mengandung simbol-simbol dengan memanfaatkan kutipan dari cerita yang dijadikan objek dan buku-buku penunjang yang berkaitan dengan pengungkapan makna.

Penelitian dengan pendekatan semiotik terhadap cerpen Surau karya Khairul Jasmi didasarkan pada alasan bahwa cerpen yang dipilih untuk dianalisis memuat banyak simbol yang memerlukan pemaknaan.

Data dalam penelitian ini adalah simbol-simbol yang terdapat dalam cerpen yang dianalisis. Sumber data adalah cerpen yang berjudul Surau karya Khairul Jasmi.

\section{Pembahasan}

Dalam penelitian ini pendekatan atau teori yang digunakan adalah teori struktural semiotik. Oleh sebab itu, akan dibahas mengenai teori struktur terlebih dahulu. Analisis struktur cerita bertujuan untuk mendapatkan susunan teks untuk menyediakan fakta-fakta yang disampaikan oleh teks (alur).

\subsection{Sinopsis Cerita Pendek Surau Karya Khairul Jasmi}

\subsubsection{Surau Terakhir Ada 22 Tahun Silam.}

Surau yang terletak di kampung Malin Torgondin terakhir ada adalah 22 tahun yang lalu. Surau tersebut hancur disebabkan banjir Galodo (banjir bandang) yang melanda desa tersebut. Seruan untuk kembali ke surau sudah lama dikumandangkan, tapi tidak mendapat sambutan yang semestinya. 


\subsubsection{Surau Terakhir Terletak di Sebuah Lekuk.}

Surau yang hilang itu terletak di sebuah lekuk, di sisi timur nagari. Di sana mengalir pula sebuah anak sungai dari gunung Merapi. Airnya dari sarasah jatuh dari gunung itu. Di tepi-tepi anak sungai tadi, ada lima kindi padi dan enam buah tebat ikan. Di sisi surau ada sebuah rumah yang tonggak-tonggaknya persis di tengahtengah tebat.

\subsubsection{Penunggu Surau Sebelum Banjir Datang}

Beberapa tahun sebelum banjir galodo datang, surau tersebut ditinggali oleh seorang pemuda yang bernama Malin Torgondin. Malin Targondin adalah seorang anak ulama yang telah lulus madrasah. Setelah lulus dari madrasah Malin Torgondin melamar kerja ke kantor-kantor tapi tidak ada satupun yang mau menerimanya. Akhirnya, Malin Torgondin tinggal di surau dan mengajar ngaji di sana.

\subsubsection{Masa Sekolah Malin Torgondin.}

Pada saat masih sekolah di madrasah, Malin Torgondin mempunyai seorang teman akrab yang bernama Bujang Betung.Malin Targondin sangat di manja oleh ayahnya. Segala permintaan saat ia masih sekolah selalu dituruti oleh ayahnya sedangkan Bujang Betung tidak. Ayah Bujang Betung bahkan pernah naik pitam saat Bujang Betung meminta kenaikan uang jajan.

\subsubsection{Nasib Bujang Betung dan Malin Targondin Setelah Tamat Sekolah Madrasah.}

Setelah tamat dari madrasah, Bujang Betung menjadi orang yang berhasil. Sebentar lagi ia hendak naik haji. la laris bagai kacang goreng, diundang mengaji dari masjid yang satu ke masjid yang lain. Bahkan ia mempunyai seorang istri yang cantik. Malin Targondin sendiri bernasib tidak sebaik Bujang Betung.Tidak ada satu kantorpun yang mau menerimanya bekerja. Akhirnya, Malin Torgondin tinggal di surau menjadi guru mengaji.

\subsubsection{Pak Karimun Teman Malin Torgondin di Surau.}

Di surau Malin Targondin mempunyai teman bernama Pak Karimun. Pak Karimun tinggal di sebuah pondok tidak jauh dari surau. la mempunyai sorang istri bernama Kirani dan seorang anak bernama Rosma.

\subsubsection{Pak Karimun Merupakan Ruh dari Surau.}

Pak Karimun merupakan ruh surau. Hal itu disebabkan ia melakukan apa saja untuk memperlancar aktivitas surau, seperti menyapu lantai, mencabuti rumput, atau membuang daun manggis yang jatuh di halaman. Pak Karimun pula yang membunyikan tabuh saat waktu salat telah datang. Dia pula yang azan, menghidupkan petromak saat malam datang. Oleh sebab itu, boleh di katakan Pak Karimun merupakan ruh dari surau itu sendiri.

\subsubsection{Pandangan Hidup Pak Karimun.}

Pak Karimun adalah orang yang sangat rajin berkerja. Selain bekerja ia juga mengurusi Surau. Pak Karimun berpandangan hidup tidak hanya di dunia saja tetapi juga di akhirat. Selain itu, Pak Karimun juga tidak menyekolahkan anaknya yang bernama Rosma disebabkan pandangannya bahwa sekolah tidak mengajarkan siswanya pelajaran agama yang cukup.

\subsubsection{Manajemen Rumah Tangga Pak Karimun}

Di pondok Pak Karimun terdapat tiga periuk nasi. Masing-masing bertanak di periuk sendiri-sendiri, secukupnya untuk sendiri pula, Karimun untuk dirinya, Kirani 
6|Mabasan, Vol. 9 No.1, Januari-Juni 2015: 1-18

untuk dirinya, dan Rosma nntuk dirinya. Lauknya pun demikian. Pak Karimun punya lauk sendiri, Kirani punya lauk sendiri, dan Rosma punya lauk sendiri. Mereka tidak mengganggu periuk satu sama lain.

\subsubsection{Tempat Penyimpanan Uang Pak Karimun.}

Pak Karimun sangat rajin bekerja. Oleh sebab itu, ia menghasilkan uang yang banyak. Akan tetapi, tidak ada yang tahu di mana Pak Karimun menyimpan uangnya. Setelah banjir galodo melanda kampung Pak Karimun baru diketahui tempat penyimpanan uang Pak Karimun, yaitu di tabung untuk ONH (ongkos naik haji).

\subsubsection{Rosma Menggantikan Pak KarimunNaik Haji}

Setelah petugas $\mathrm{ONH}$ mengetahui bahwa Pak Karimun telah meninggal akhirnya Rosma yang menggantikan Pak Karimun untuk pergi haji.

\subsubsection{Niat Gubernur untuk Mendirikan Surau Kembali.}

Beberapa tahun setelah banjir galodo, gubernur berniat akan membangun surau kembali di kampung Pak Karimun. Surau yang akan didirikan, dibangun dengan konsep modern, yaitu memakai televisi, komputer, antena digital, perpustakaan dan lain-lain.

\subsection{Analisis Semiotik Cerpen Surau}

Surau yang terakhir ada di nagari adalah 22 tahun yang lalu. Surau tersebut musnah karena diterjang galado (banjir bandang). Hal itu terlihat dalam kutipan berikut ini.

"Dulu ada, tapi sudah punah dilanyau banjir bandang, galodo. Surau terakhir di nagari kami ada 22 tahun silam, setelah itu yang ada hanya tapak surau yang kini sudah ditumbuhi ilalang, gulma busuk dan papaya jantan. Surau memang bak pepaya jantan itu, bunganya lebat, tapi tak berbuah.Namun, kalau awak sakit, mulai dari akar sampai daunnya bisa dijadikan obat. Tapi siapa pula sekarang yang mau menjadikan pepaya jantan sebagai obat. Orang kini berobat ke Puskemas, meski obatnya asal jadi. Meski dokternya jarang ada di sana." (Khairul, 1999:23)

Dari kutipan di atas ada beberapa hal yang dapat dipandang sebagai simbol. Pertama, surau yang musnah selama 22 tahun merupakan simbol yang bermakna kemunduran kehidupan bergama di kampung tersebut sudah berada dalam taraf yang paling rendah. Hal itu disebabkan surau merupakan tempat salat umat Islam secara berjamaah dan hal itu merupakan ibadah yang menjadi kewajiban kaum muslimin di manapun mereka berada. Jika surau di suatu wilayah tidak ada dapat dipastikan kegiatan salat berjamah di tempat itu sudah tidak ada. Rasulullah SAW mengatakan dalam suatu riwayat bahwa "buhul atau simpul Islam akan terlepas satu persatu yang pertama adalah pemerintahannya (kekhilafahan) dan yang terakhir adalah salat." Oleh sebab itu jika surau di kampung tidak ada berarti keadaan kehidupan beragama tersebutsudah berada dalam taraf yang paling rendah.

Selain sebagai tempat salat, surau juga berfungsi sebagai tempat pengkaderan bagi kaum muslimin selanjutnya. Di surau, anakanak kaum muslimin belajar mengaji dan mempelajari agama. Bila surau di sebuah kampung tidak ada dapat dipastikan kehidupan beragama di kampung tersebut telah mati.

Kedua, pengibaratan surau dengan pepaya jantan yang tidak berbuah merupakan simbol yang mengandung makna fungsi surau sebagai tempat ibadah dan pembinaan umat tidak berjalan sebagaimana mestinya. Surau merupakan tempat yang 
... Suatu Analisis Semiotik (Agus Yulianto)| 7

ideal dalam membina umat. Dari sana diharapkan akan lahir orang-orang yang saleh. Orang-orang yang dapat membawa kehidupan ke arah yang lebih baik. Akan tetapi, pada kenyataannnya surau berfungsi sebagai tempat ibadah ritual belaka dan tidak dapat memberikan sumbangsih apaapa bagi kemajuan umat. Hal itu dapat terjadi semata-mata karena kesalahan dari memaknai fungsi surau itu sendiri. Fungsi surau atau masjid sebenarnya bukan sebagai tempat salat saja. Fungsi surau dan masjid seperti di zaman Rasulullah SAW adalah sebagai tempat menuntut ilmu, menyusun strategi perang, tempat musyawarah, tempat memikirkan masalah umat, perputaran ekonomi seperti zakat, infaq, dan sodaqoh dan masih banyak lagi fungsi surau yang lainnya. Sekarang ini fungsi surau telah berkurang sangat drastis, yaitu sebagai tempat untuk salat saja. Oleh sebab itu, kemandulan surau dalam membina umat lebih disebabkan oleh adanya degradasi dari fungsi surau itu sendiri. Bahkan, saat ini fungsi surau sebagai tempat untuk melaksanakan salat berjamaahpun sudah ditinggalkan oleh masyarakat.Sudah menjadi rahasia umum banyak surau dan masjid didirikan dengan megah tetapi kosong dari jamaah.Hal itu berarti umat Islam sekarang ini sudah banyak yang meninggalkan kewajiban salat berjamaah.

Ketiga, pengibaratan surau dengan pepaya jantan yang dapat dijadikan obatyang juga sudah ditinggalkan masyarakat merupakan simbol yang mengandung makna fungsi surau sebagai tempat untuk bermunajat kepada Allah SWT bagi orangorang yang mencari obat bagi jiwa yang gersang karena terlalu mengejar kehidupan keduniawian dan melupakan akhirat juga sudah mulai ditinggalkan. Masyarakat sekarang mencari alternatif lain dalam mengisi kekosongan jiwanya. Mereka lebih memilih pergi ke tempat-tempat rekreasi, hiburan atau bahkan bermeditasi dibandingkan harus ke surau untuk mengingat Tuhan-nya. Padahal Alquran sudah memberitahukan bahwa "orang-orang beriman hati mereka menjadi tenang tentram dengan mengingat Allah SWT, Sesungguhnya hanya dengan mengingat Allah SWT saja hati menjadi tenang."

Seruan untuk kembali ke surau sudah dikumandangkan. Bahkan bertahun-tahun tetapi tidak ada yang peduli. Apalagi ulama sudah tidak ada. Hal itu tampak dalam kutipan berikut.

"Sekarang memang ada seruan 'kembali ke surau'. Tapi belum ada yang berbuat, padahal seruan itu sudah bertahun-tahun dikumandangkan. Mungkin hanya aku yang benar-benar berfikir ke arah itu, tapi siapa yang percaya. Lagi pula, ulama sudah tidak ada lagi. Jikapun ada mereka hanya ibarat pepaya jantan tadi, kadangkadang seperti Alquran tua. Sebagaimana jamaknya, Alquran tua, sudah lapuk, sudah berdebu, halamannya sudah banyak yang robek dan hilang. Kalau dibuang, rasa akan berdosa, kalau disimpan di sembarang tempat, nanti terlangkahi, berdosa awak dibuatnya. Kalau berdosa janganlah, apalagi amal kebajikan juga kurang, bersedekah jarang. Bagaimana takkan jarang, uang susah, hidup pahit. Agar aman, agar tak berdosa, maka Alquran tua tadi, ditarok saja di atas kepala almari. Berdebulah di sana, sekali setahun dibersihkan. Itupun kalau sempat." (Khairul, 1999:23--24)

Dari kutipan di atas ada beberapa hal yang dapat di pandang sebagai simbol. Pertama, seruan kembali ke surau merupakan simbol yang mengandung makna masih ada sisa-sisa kesadaran pada warga untuk menghidupkan kembali kehidupan keagamaan di kampung tersebut. Kesadaran tersebut dinamakan fitrah manusia. Berdasarkan fitrahnya, manusia tidak 
mungkin dapat menghilangkan naluri untuk menyembah Tuhan. Oleh sebab itu, sebenarnya sekafir apapun seseorang pasti terdapat potensi untuk mengenal Allah SWT. Hanya saja manusia kafir tersebut telah mematikan potensi fitrah tersebut dan mengikuti hawa nafsunya.

Kedua, ketiadaan ulama merupakan simbol yang mengandung makna tidak ada regenerasi atau pengkaderan orang-orang yang mempelajari dan memahami ilmu-ilmu agama. Hal itu secara tidak langsung juga menunjukkan sedikitnya animo masyarakat dalam mempelajari ilmu-ilmu agama. Mereka lebih menyukai mempelajari ilmuilmu dunia. Padahal mempelajari ilmu-ilmu agama itu hukumnya fardhu a'in (kewajiban setiap individu) dan mempelajari ilmu-ilmu dunia hukumnya fardhu kifayah (kewajiban tersebut gugur bila ada orang muslim yang sudah mempelajari dan menguasai ilmu tersebut).

Dalam sistem sekuler, dunia pendidikan mempunyai peran yang strategis dalam menciptakan manusia-manusia yang berpaham sekuler. Dengan demikian terciptalah dikotomi pendidikan agama dengan pendidikan umum. Sudah menjadi rahasia umum bila dunia pendidikan yang berbasis agama Islam menjadi dunia pendidikan kelas duasetelah pendidikan umum. Lapangan kerja juga terkondisikan lebih banyak menyerap lulusan siswa yang berasal dari pendidikan umum. Oleh sebab itu, tidak heran bila animo masyarakat untuk menyekolahkan anaknya di sekolah umum lebih besar dibandingkan menyekolahkan anaknya di sekolah yang berlandasankan agama, khususnya dunia pendidikan agama Islam.

Ketiga, Alquran tua yang berdebu merupakan simbol yang mengandung makna Alquran sudah tidak terlalu dihiraukan lagi. Ajaran-ajaran yang terdapat di dalamnya sebagian besar sudah tidak dijalankan. Contohnya praktek ekonomi berdasarkan riba, zinah, minuman keras, membunuh, berjudi, dan masih banyak lagi perkara yang dilarang dalam Alquran sudah menjadi bagian hidup sehari-hari. Oleh sebab itu, tidak heran bila negeri ini sering di landa bencana. Padahal bila penduduk suatu negeri mau menjalankan perintah-perintah yang terdapat dalam Alquran suda dipastikan berkah Allah SWT akan turun dari langit dan bumi dan itu merupakan janji Allah yang pasti akan terjadi. Saat ini umat Islam jauh dari Alquran. Jangankan berusaha untuk memahami isinya dan mengamalkannya, membaca saja sudah tidak dilakukan lagi. Padahal Rasulullah Saw mengatakan "barang siapa yang berpegang pada Alquran dan hadis pasti akan selamat dunia dan akhirat. Umat Islam adalah umat yang terbaik yang dilahirkan bagi manusia, menyeru kepada yang ma'ruf dan mencegah dari yang munkar serta beriman kepada Allah SWT. Kunci meujadi umat yang terbaik tersebut adalah bila umat Islam berpegang pada Alquran dan melaksanakan hukum-hukum yang ada di dalamnya pada seluruh aspek kehidupan. Saat ini umat Islam hanya menjalankan sebagian isi Alquran dan meninggalkan sebagian lainnya. Contohnya mereka berpuasa di bulan Ramadhan sebagai suatu kewajiban dari Allah SWT seperti yang terdapat dalam Alquran tetapi mereka tidak menjalankan hukum qisas bagi yang terbunuh yang juga merupakan perintah Allah SWT yang terdapat dalam Alquran, atau hukum potong tangan bagi pencuri, ta'zir bagi orang yang meninggalkan salat dan meminum kamar. Padahal Allah SWT melarang bagi orang yang beriman untuk menjalankan sebagian isi alkitab dan meninggalkan sebagian lainnya. Hal inilah yang menjadi sebab umat Islam mengalami kemunduran seperti saat ini.

Beberapa tahun sebelum banjir bandang datang, surau tersebut diisi oleh seorang pemuda yang bernama Malin 
... Suatu Analisis Semiotik (Agus Yulianto)

Targondin. la sudah lulus dari madrasah tetapi tidak mendapatkan pekerjaan. Oleh sebab itu, ia akhirnya mengurusi surau. Hal itu seperti terlihat dalam kutipan di bawah ini.

"Bagi pemuda itu mandi pagi bukanlah sesuatu yang berat. Kebiasaan mandi pagi, ia dapatkan waktu masul: madrasah dulu. Setelah tamat ia kembali ke kampung, menganggur. Tak ada kantor yang mau menerimanya bekerja. Satusatunya manfaat sekolah yang ia rasakan adalah soal mandi pagi itu." (Khairul, 1999:25)

Nasib Malin Targondin yang menganggur setelah lulus dari madrasah karena tidak ada kantor yang menerimanya merupakan simbol yang mengandung dua makna. Pertama, hal itu menunjukkan sistem perekrutan tenaga kerja lebih berpihak pada lulusan sekolah-sekolah umum. Sudah menjadi rahasia umum bila sekolah-sekolah yang berbasis agama Islam seperti madrasah dan yang lainnya merupakan anak tiri dalam sistem pendidikan nasional. Madrasah, pesantren merupakan lembaga pendidikan kelas dua. Sekolah umumlah yang lebih dinomorsatukan. Oleh sebab itu, banyak pesantren dan madrasah yang mengalami kerusakan fisik seperti gedung sekolahnya hampir roboh dan sebagainya. Hal itu merupakan cerminan dari sistem sekuler yang dianut oleh sistem pendidikan kita.

Kedua, kualitas tamatan pesantren atau madrasah yang terkadang harus diakui belum memenuhi standar bagi dunia pekerja. Mereka biasanya ahli di bidang ilmu agama tetapi lemah dibidang ilmu-ilmu dunia, kalah oleh lulusan sekolah-sekolah umum. Oleh sebab itu, tidak heran bila Malin Targondin satu-satunya manfaat sekolah yang ia rasakan adalah soal mandi pagi itu." (Khairul, 1999:25)
Pada waktu Malin Targondin masih sekolah di madrasah, ia mempunyai seorang teman dekat yang bernama Ujang Betung. Malin Targondin termasuk anak yang di manja oleh ayahnya. Berbeda dengan Ujang Betung. Hal itu terlihat dalam kutipan berikut.

"Si Ujang teman akrabku ini kepadaku. Katanya, "Aku ingin minta tambahan jajan pada ayah tapi tak bisa, beliau datang, lantas pergi tanpa banyak cakap, lain dengan kau," katanya. Memang lain. Kalau aku, ayah datang bersama ayah Ujang Betung. Ayah Ujang Betung pulang, ayahku menunggu aku pulang sekolah. Begitu pulang, ayah tersenyum. "Sudah lapar?" "lya," jawabku. "Ayo kita makan ke pasar," ajak ayah. Kalau sudah ke pasar, bukan hanya makan, tapi juga minum, beli peci, beli baju, beli kue, paniaraman, lepat, lemang limakaum, pokoknya betul-betul lepas seleraku dibuatnya. Nanti bila sudah sore, aku diantar lagi ke rumah sewaanku dekat sekolah. Tak lupa ayah menyelipkan uang tambahan. "Apa cukup uang tadi?" Tanya ayah. Aku tak menjawab dan ayah dengan sigap menyelipkan tambahan itu ke saku-sakuku. Aku sekolah dengan uang cukup, perhatian yang tinggi dantingkat kemanjaan yang aduhai. Sementara Ujang Betung darikelas satu sampai tamat, uang jajannya tak pernah ditambah ayahnya. Pernah sekali ia minta tambah, ayahnya naik pitam. "Kamu kira aku dan ibumu membuat uang di kampung," kata ayahnya. Bujang Betung menunduk sedih.” (Khairul, 1999:25--26)

Kutipan di atas terdapat simbol, yaitu memanjakan anak merupakan simbol yang mengandung makna kasih sayang. Setiap orang tua pasti akan mengasihi dan menyayangi anaknya. Bahkan walaupun anak tersebut lahir dari hasil hubungan 
haram. Hal itu merupakan sunatullah yang sudah ditetapkan Allah SWT. Hanya saja dalam menunjukkan rasa kasih dan sayang terhadap anak tersebut terkadang berbeda. Tergantung persepsi dan sudut pandang masing-masing orang tua. Ada orang tua yang berpandangan dengan menuruti semua kemauan sang anak merupakan wujud dari kasih dan sayang. Akan tetapi, mengajarkan anak untuk prihatin dan tidak selalu menuruti kemauan sang anak juga agar anak mengetahui arti sebuah perjuangan merupakan wujud dari rasa kasih dan sayang. Dalam kasus Bujang Betung dapat diketahui barkat sikap ayahnya yang mengajarkan sikap prihatin dan tidak mudah untuk meluluskan permintaan sang anak agar anak mengetahui arti sebuah perjuangan dikemudian hari terbukti hasilnya baik. Setelah Bujang Belitung selesai sekolah madrasah, ia mudah mencari pekerjaan dan berhasil menjadi orang kaya, sedangkan Malin Torgondin bernasib sebaliknya, tidak ada satu kantor pun yang mau menerimanya bekerja. Bahkan, pekerjaan Malin Torgondin akhirnya hanya mengurusi surau saja. Hal itu terlihat dalam kutipan berikut.

"Tapi kini, aku yang sedih. Setelah beberapa tahun tamat sekolah. Aku tidak bisa mengapa-ngapa. Aku hanya pandai mengaji, itupun tidak seberapa. Aku lebih mahir menembak burung, ketimbang yang lain. Sebab sejak sekolah dulu, aku sudah pakai bedil angin yang dibelikan ayah. Katanya untuk merintang-rintang waktu. Akan halnya Bujang Betung, sebentar lagi akan naik haji. la laris bagai kacang goreng, diundang orang mengaji dari masjid yang satu ke masjid yang lain. Dari nagari yang satu ke nagari yang lain. Jadwalnya sudah padat. Otaknya makin lama, kian terang saja. Makin banyak saja kajinya. Bukunya juga kian banyak. Dan isterinya cantik pula.Aku benar-benar iri. Aku mau marah, tapi aku sudah 'sesat air', dimanjakan ayah waktu sekolah, sehingga aku jadi lembek. Sampai kini orang sudah berbini, aku belum juga."

(Khairul, 1999:26--27)

Di surau, Malin Torgondin berteman dengan seorang bapak yang bernama Karimun. Pak Karimun mempunyai istri yang bernama Kirani serta seorang anak yang bernama Rosma. Mereka tinggal di pondok yang letaknya tidak jauh dari surau.

Pak Karimun mempunyai kebiasaan buruk, yaitu suka mengambil daging korban yang belum menjadi haknya. Malin Torgondin sangat tidak menyukai perbuatan Pak Karimun tersebut. Hal itu terlihat dalam kutipan berikut.

"Karimun, agak rakus dengan daging
korban. Belum-belum dia sudah
menyurukkan beberapa potong daging,
padahal menurut ajaran agama hal itu
tidak boleh dilakukan. Waktu ia
bereaksi aku diam saja. Sebab aku
tahu, ia akan segera mengantarkan ke
pondoknya. Begitu ia pergi aku susul
dengan mengendap-endap kembali ke
surau aku juga kembali. la kembali
dengan tangan kosong, aku kembali
membawa daging yang tadi ia curi."
(Khairul, 1999:27)

Perbuatan Pak Karimun mengambil daging korban yang dianggapnya tidak salah merupakan simbol yang mengandung makna "pemahaman agama yang salah". Pak Karimun berpendapat ia tidak mencuri daging korban. Hal itu ia lakukan sematamata sebagai upah bagi orang yang bertugas menyembelih hewan kurban dan membagikannya kepada penduduk. Malin Targondin berpendapat lain. Perbuatan Pak Karimun dianggapnya sebagai tindakan pencurian. Hal itu disebabkan Malin Targondin mempunyai pemahaman orang yang bertugas menyembelih hewan kurban 
dengan orang yang menerima daging hewan kurban mempunyai jatah yang sama.

Pak Karimun adalah orang yang bertugas memelihara surau. Baik menyapu lantai, mencabuti rumput, atau membuang daun manggis yang berguguran. Pak Karimun tidak hanya rajin membersihkan surau. Ia ibarat ruh surau. Hal itu terlihat dalam kutipan berikut.

"Bukan hanya rajin membersihkan halaman surau, tapi ia merupakan ruh dari surau itu. Kalau Pak Karimun sakit, sepertinya surau ikut pula sakit. Kalau ada warga kampung yang mau menitipkan barang sehari dua, pada Karimunlah mereka menitipkan. Menitipkan cangkul, sabit, bajak yang enggan dibawa pulang, maka dititipkanlah pada Karimun. la akan menerima dengan suka cita. Karimunlah yang membunyikan tabuh tiap waktu shalat masuk. Dia pula yang azan, tapi tak pernah jadi imam. Karimun pula yang menghidupkan petromak setiap senja datang. Kalau kelalawar sudah keluar dari ujung tabuh, maka Karimun segera memukul tabuh itu. Katanya pertanda maghrib sudah datang. Pokoknya ia punya patokan baku untuk dipakai kapan waktu shalat lima waktu masuk. Dan itu, biasanya tidak meleset. Hebat juga Pak Karimun ini." (Khairul, 1999:28)

Dari kutipan di atas terdapat beberapa simbol sebagai berikut. Pertama, ruh surau merupakan simbol yang mengandung makna "nafas kehidupan surau". Surau sebagai tempat ibadah memiliki aktivitas-aktivitas keseharian yang harus dilakukan, seperti memukul tabuh, azan, salat berjamaah, sampai menghidupakan patromak bila malam datang, dan semua itu dikerjakan oleh Pak Karimun. Oleh sebab itu, Pak Karimun seakan-akan seperti nafas kehidupan surau.
Kedua, Banyak tetangga menitipkan barang kepada Pak Karimun merupakan simbol yang mengandung makna "amanah atau terpercaya". Masyarakat tahu bila mereka menitipkan sesuatu barang kepada Pak Karimun pasti barang itu tidak akan hilang atau rusak. Pak Karimun adalah orang yang sangat rajin mencari nafkah, tetapi tetap mengurusi surau. la berpendapat hidup tidak hanya untuk dunia, tapi juga akhirat. Hal itu terlihat dalam kutipan berikut.

"la mencari nafkah dengan rajin, tapi
tak lupa mengurus surau. "Hidup ini
tidak hanya untuk dunia, tapi juga
untuk akhirat," katanya suatu ketika
padaku. Isterinya juga rajin mencari
nafkah. Entah mana yang punya
penghasilan lebih besar, aku tidak tahu
pasti. Sementara anaknya juga
mencari nafkah. Rajinnya bukan main.
Mungkin karena itu, ia terlambat
bersuami." (Khairul, 1999:28--29)

Pandangan hidup Pak Karimun yang menyatakan hidup tidak hanya di dunia tapi juga di akhirat merupakan simbol yang mengandung makna pemahaman Islam yang benar. Islam mengajarkan tidak ada pemisahan antara kehidupan dunia dengan akhirat. Islam melarang orang untuk mengejar kepentingan dunia saja dan melupan akhirat atau sebaliknya mengejar akhirat saja dan melupakan dunia. Islam mengajarkan hidup itu harus seimbang (tawazun).

Pak Karimun sangat rajin mencari nafkah untuk kehidupannya di dunia dan dia sangat rajin mengurusi surau untuk kepentingannya nanti diakhirat. Pak Karimun tidak diam saja, berdo'a mengharapkan rizki turun dari langit melainkan ia bekerja. Pak Karimun juga tidak hanya menginginkan surga tanpa usaha melainkan ia rajin beribadah. Dalam pandangan Islam semua aktivitas dari kehidupan manusia bernilai ibadah asal 
diniatkan untuk mencari keridhaan Allah SWT. Orang yang mencari nafkah untuk keluarga itupun termasuk dalam lingkup ibadah asal semata-mata diniatkan untuk rnencari keridhaan Allah SWT. Pandangan hidup Pak Karimun yang lain terdapat dalam kutipan berikut.

\begin{abstract}
"Meski rajin dan cukup uang, mereka tetap tinggal di pondok dekat surau. Alasan keluarga ini, agar dekat dengan air dan dekat pula dengan surau." Untuk apa membangun rumah, hidup hanya sebentar, pondok ini cukup untuk kami bertiga," kata Pak Karimun padaku. Kalau Rosma ada jodoh, "biarlah junjungannya nanti yang membuatkan tempat berteduh untuknya," katanya. Kalau soal sekolah, katanya melanjutkan, aku tidak mau anakku masuk sekolah umum itu. Ketika aku tanya apa alasannya, rupanya ia menganggap sekolah umum itu selain banyak pelajaran kafirnya, juga tidak ada gunanya. "Mana urusan akhiratnya di situ, tolong kau tunjukkan padaku yang bodoh ini," kata dia." (Khairul, 1999:29)
\end{abstract}

Dari kutipan di atas dapat diketahui bahwa pandangan hidup Pak Karimun merupakan simbol yang mengandung makna "pemahaman hidup yang benar". Hal itu didasarkan kepada penjelasan berikut ini. Pertama, kehidupan manusia di dunia tidaklah abadi. Manusia pasti akan mengalami kematian dan menjalani kehidupan di akhirat. Baik buruknya kehidupan di akhirat sangat tergantung oleh perbuatannya di dunia. Orang-orang yang mengerti akan hal ini cenderung memperlakukan hidup di dunia hanya sebagai tempat persinggahan saja. Mereka mengambil kebutuhan di dunia seperlunya saja. Hal itu didasarkan pada pemahaman bahwa semakin banyak perkara di dunia yang di sentuhnya maka akan semakin panjang pula proses perhitungan (hisab) dan pertanggungjawabannya di akhirat. Dengan kata lain, semakin kaya harta seseorang akan semakin lama proses perhitungannya di akhirat mengenai harta yang dimilikinya itu.

Kedua, sekolah umum adalah sekolah dengtan sistem pendidikan sekuler atau memisahkan urusan agama dengtan urusan dunia. Pelajaran agama yang terdapat di sekolah umum sangat sedikit sekali dan itu pun sebatas pada teori saja. Sekolah umum tidak mewajibkan siswanya untuk langsung mempraktekkan ajaran agama yang diterimanya. Contohnya pelajaran tentang salat. Sekolah umum hanya mengajarkan teorinya saja (hukum fikih) tetapi tidak langsung mewajibkan siswa untuk mengamalkannya. Hal itu sangat berbeda dengan pola pendidikan pesantren yang juga mengedepankan aspek amaliah dari beribadah. Oleh sebab itu, biasanya di pesantren kaum wanitanya mengenakan jilbab sedangkan di sekolah umum tidak. Di pesantren, para santri langsung disuruh salat sebagai bagian dari pendidikan sedangkan di sekolah umum tidak. Pendek kata, sekolah umum tidak memberikan porsi yang semestinya bagi pendidikan agama.

Pak Karimun mempunyai cara yang unik dalam mengatur urusan rumah tangganya. Hal itu terlihat dalam kutipan berikut.

"Yang unik bukan kehidupannya dan cara ia mencari nafkah itu, tapi yang ini: Di pondok itu ada tiga periuk nasi. Yang satu punya Karimun, yang dua lainnya punya isteri dan anaknya. Ketiganya bertanak nasi sekali sehari. Pagi saja. Masing-masingnya bertanak di periuk sendiri-sendiri, secukupnya untuk diri sendiri pula. Karimun untuk dirinya, Kirani untuk dirinya dan Rosma untuk dia pula. Jelimet benar mereka soal nasi. Soal lauknya juga begitu. Karimun punya lauk sendiri, apakah ikan sepat, atau belut atau apa saja. Tidak akan pernah disentuh oleh 
isteri dan anaknya, sebaliknya juga demikian. Tapi mereka makan samasama. Mereka punya sepiring sawah yang tidak terlalu besar. Hasilnya dibagi tiga pula. Karimun punya tempat penyimpanan uang sendiri, begitu pula yang lainnnya. Kalau Kirani ke pasar, Karimun akan berkirim agar dibelikan telur itik atau kerupuk piladang. Kalau Karimun yang ke pasar, biasanya isterinya berkirim lemang limo kaum, atau martabak. Sabun mandi sendirisendiri, odol tidak ada, cukup daun banto. Handuk juga tidak, cukup kain basahan. Sterika tidak perlu, sebab mereka memang tidak membutuhkan. Kehidupan yang seperti itu dijalani dengan damai. Tidak seorangpun yang mengeluh pada anggota keluarga lainnya. Yang sesak nafas hanyalah orang lain saja. Panas tadan dari cawan. Namun untuk soal ini, aku memberanikan diri untuk bertanya." (Khairul, 1999:30)

Pengaturan urusan rumah tangga di rumah Pak Karimun merupakan simbol yang mengandung makna penyimpangan dari konvensi pengaturan rumah tangga pada umumnya. Dalam pandangan Islam, harta suami adalah harta istri, tetapi harta istri bukan harta suami. Oleh sebab itu, tindakan Pak Karimun yang membagi tiga setiap urusan rumah tangga tidak dapat dibenarkan. Apapun alasannya. Pak Karimun tidak boleh melarang istri dan anaknya untuk menyentuh periuk nasinya.

Pak Karimun juga memiliki banyak uang tabungan hasil kerja kerasnya selama ini. Akan tetapi, tidak ada seorang warga pun yang mengetahui di mana Pak Karimun menyimpan uangnya. Hal itu terlihat dalam kutipan berikut.

\footnotetext{
"Jadi uang Pak Karimun yang sudah banyak itu untuk apa gunanya?"

"Jangan pula kau masuk ke bilik kecil orang, urus saja urusanmu!" la marah
}

besar. la tidak ingin orang tahu kalau ia banyak uang. la sangka orang memang tidak tahu. Padahal tidak ada orang di nagari kami yang tidak tahu kalau ia banyak uang. la kaya, tapi kikir. Tidak saja pada orang lain, tapi juga pada diri sendiri. Setahuku, ia selalu bercelana setengah tiang. Sampai di lutut saja. Ikat pinggang besar. Di ikat pinggang besar itulah, sering ia menyelipkan uangnya. Rupiah emasnya, entah diman aia surukkan. Aku sudah berusaha mengintainya, tapi tidak pernah bisa mengetahuinya." (Khairul, 1999:31-32)

Perbuatan Pak Karimun yang suka menyembunyikan uangnya merupakan simbol yang mengandung makna kehatihatian. Pak Karimun tidak mau mengambil resiko bila ada orang yang tahu di mana ia menyimpan uang maka uangnya tetap aman. Pak Karimun lebih memilih sikap tidak takabur atau sombong karena rizki yang yang diperolehnya. la tetap bersikap seolaholah ia tidak mempunyai banyak uang.

Rahasia tempat penyimpanan uang Pak Karimun baru diketahui saat banjir bandang melanda kampungnya. Lebih dari tiga puluh orang tewas akibat banjir bandang itu. Pak Karimun dan istrinya ikut tewas sedangkan Rosma dan Malin Torgondin selamat karena pada saat banjir melanda mereka sedang pergi ke pusat nagari. Hal itu tampak dalam kutipan berikut.

\footnotetext{
"Aku selamat, bukan karena apa-apa, tapi waktu galodo tiba. aku tidak sedang di surau. Malam itu, aku asyik mendengarkan orgen tunggal di pusat nagari. Anak-anak yang tidur di surau, malam itu, pergi bersamaku, maklum ada acara baralek, pesta pernikahan family Rosma. Di sanalah orgen tunggal itu dimainkan. Penyanyinya dari kota kabupaten. Wanita, tiga orang. Cantik-cantik lagi. Pakaiannya ketat-ketat. Malu aku melihatnya, tapi
} 
Mabasan, Vol. 9 No.1, Januari-Juni 2015: 1-18

apa boleh buat, kapan lagi melihat hiburan. Karena Pak Karimun dan isterinya sudah tua, maka yang pergi hanyalah Rosma. Rosma dengan demikian juga selamat dari bencana galodo.” (Khairul, 1999:32)

Malin Torgondin dan Rosma yang selamat dari banjir galodo merupakan simbol yang mengandung makna ajal manusia yang menentukannya adalah Allah SWT. Malin Torgondin dan Rosma selamat dari musibah banjir disebabkan ajal mereka pada hakekatnya belum saatnya datang. Kepergian mereka ke pusat kota sehingga mereka selamat dari musibah banjir bukan merupakan suatu kejadian yang kebetulan saja terjadi. Akan tetapi, kepergian mereka tersebut sudah menjadi rencana Allah SWT yang menyebabkan mereka selamat dari musibah banjir.

Sepuluh hari setelah musibah banjir melanda kampung Malin Torgondin, petugas ONH (ongkos naik haji) datang mencari Pak Karimun. Petugas mengatakan bahwa Pak Karimun telah melunasi ONH-nya sehingga ia berhak untuk naik haji. Warga kampung akhirnya mengetahui bahwa selama ini Pak Karimun telah menyimpan uangnya untuk ongkos naik haji. Pak Karimun telah tiada, tewas akibat banjir galodo yang melanda kampungnya. Akhirnya Rosma berangkat naik haji menggantikan bapaknya. Hal itu terlihat dalam kutipan berikut.

"Namun, sepuluh hari kemudian orang dikejutkan oleh petugas haji yang datang dari kabupaten. Ia mencari rumah Pak Karimun. Setelah diterangkan, petugas haji itu menarik nafas panjangnya. "Kalau begitu, harus ada orang yang menggantikannya untuk naik haji, sebab almarhum sudah melunasi ONH-nya," kata dia. "Oooh..." kata orang kampung. Pak Karimun rupanya diam-diam mau naik haji. Pantas dalam beberapa bulan belakangan ia sering ke kota kabupaten. Pergi manasik rupanya dia. Tapi sebelum berangkat Tuhan memanggilnya. Lantas siapa yang harus naik haji? Tak lain, tentulah anaknya: Rosma. Maka naik hajilah Rosma, dengan uang ayahnya. Uang yang selama ia dinilai mulai dewasa dan pandai mencari, tidak pernah ia cicipi. Kini tiba-tiba Tuhan memberikan seutuhnya pada Rosma. la bangga sekaligus sedih. Bangga karena bisa naik haji. Sedih karena orangtuanya yang bercita-cita naik haji, ternyata tidak diizinkan Tuhan. Sedih karena ia kehilangan kedua orangtuanya sekaligus. Sedih, karena ia tidak bisa tulis baca. Karena tidak disekolahkan oleh orangtuanya. (Khairul, 1999:32--33)

Dari kutipan di atas terdapat beberapa simbol. Pertama, sikap Pak Karimun menyembunyikan niat untuk pergi haji merupakan simbol yang mengandung makna niat pergi haji Pak Karimun semata-mata karena Allah SWT. Pak Karimun tidak memerlukan pujian makhluk yang membuat dia harus memberitahukan kepada orang-orang tentang niat pergi hajinya itu. Dari kasus ini pula dapat dipahami bila Pak Karimun mempunyai konsep tauhid yang tinggi. Pak Karimun menyadari segala aktivitas ibadah harus ditujukan semata-mata untuk Allah SWT bukan karena sebab yang lain, baik itu karena manusia atau sebab-sebab lain. Bila Pak Karimun beribadah masih disebabkan oleh selain Allah SWT berarti ia secara tidak langsung menyekutukan Allah SWT dengan sesuatu hal.

Kedua, kesedihan Rosma karena tidak bisa baca tulis mempakan simbol yang mengandung makna perasaan menyesal dan rendah diri. Rosma menyadari untuk mengarungi kehidupan dibutuhkan ilmu untuk bertahan hidup. Sementara itu, Rosma tidak mempunyai cukup bekal ilmu. 
Ketiga, pendirian Pak Karimun untuk tidak menyekolahkan Rosma merupakan simbol yang mengandung makna 'pandangan yang salah terhadap ajaran Islam." Ilmu adalah cahaya. Islam mengajarkan menuntut ilmu itu wajib. Fardhu a'in untuk ilmu agama dan fardhu kifayah untuk ilmu-ilmu dunia. Bahkan Rasulullah Saw menyuruh umatnya untuk menuntut ilmu sampai ke negeri Cina. Dari perintah ini dapat dipahami menuntut ilmu dunia pun sangat dianjurkan dalam Islam. Hal itu disebabkan umat Islam tidak mungkin di suruh menuntut ilmu agama ke negeri Cina karena pusat ilmu agama ada di Mekah dan Madinah.Jadi dapat dipastikan ilmu yang dituntut sampai ke negeri Cina adalah ilmu dunia. Patut diketahui pada saat itu negeri Cina memang merupakan suatu negeri yang maju peradabannya. Jadi, Islam memandang memuntut ilmu duni dan menuntut ilmu agama sama-sama penting.

Beberapa tahun setelah banjir bandang terjadi di kampung Pak Karimun, gubernur berniat untuk mendirikan surau kembali. Akan tetapi, Hajjah Rosma menolak keinginan gubernur tersebut. Keinginan gubernur itu disampaikan pada saat acara pelantikan wali nagari.

"Pak Gubernur, tadi bapak bilang kembali ke nagari juga kembali ke surau. Ampun Pak, saya tidak mau lagi kembali ke surau. Kedua orangtua saya tewas karena surau itulah. Kalaulah ia tidak berkeras hati tinggal di dekat surau, mungkin kini kedua orangtua saya itu masih hidup. Jangan surau lagi, jangan! (Khairul, 1999:34)

Dari kutipan di atas terdapat beberapa simbol. Pertama, sikap Hajjah Rosma menolak seruan kembali ke surau mengadung makna Hajjah Rosma mengalami trauma psikologis. la masih takut dan belum lupa penyebab orang tuanya meninggal disebabkan tinggal di dekat surau.

Kedua, sikap Hajjah Rosma yang menyatakan penyebab orang tuanya meninggal karena tinggal di dekat surau merupakan simbol yang mengandung rnakna Rosma belum paham tentang masalah takdir Allah SWT. Rosma tidak menyadari bahwa kematian kedua orang tuanya merupakan takdir Allah SWT. Banjir hanya menjadi penyebab saja. Islam mengajarkan ketika seorang manusia lahir sudah ditetapkan tiga perkara baginya, yaitu jodohnya, rizkinya, dan kapan ia mati. Oleh sebab itu, Alquran menyatakan bila ajal sudah datang, tidak akan ada manusia yang dapat menghindarinya walaupun ia bersembunyi di dalam benteng yang kokoh.

Sikap Hajjah Rosma menolak untuk kembali ke surau didasarkan pada anggapan bahwa surau yang akan dibangun sama dengan surau yang dulu, sedangkan maksud gubernur surau yang akan dibangun adalah surau dengan konsep modern. Hal itu terlihat dalam kutipan berikut.

\footnotetext{
"Maksud saya bukan kembali ke surau yang dulu, tapi kita hidupkan lagi pengajian-pengajian seperti di surau itu dulu. Tempatnya bisa di mana saja, mungkin di masjid atau di dekat sekolah ini, di mana saja." "Caranya Pak?" "Jadi sekarang kita perkuat lagi surau kita. Jika dulu surau pakai petromak, sekarang pakai listrik. Jika dulu pakai rotan, kini tidak lagi. Jika dulu orang tidur di surau, kini mungkin tidak begitu. Jika dulu, surau kayu, kini surau beton. Jika dulu gurunya hanya satu ke depan kita datangkan dari kabupaten. Surau sekarang boleh pakai televisi, antena digital, komputer, sebentar lagi pakai telepon, pakai internet, pakai perpustakaan. Kalau ada yang mau naik haji, pelajari seluk beluk bangsa Arab dulu lewat buku, lihat dulu kota Mekkah lewat buku, koran. Jadi surau
} 
Mabasan, Vol. 9 No.1, Januari-Juni 2015: 1-18

kita surau yang sudah maju. Kita lakukan inovatif, pembaharuan, globalisasi sebentar lagi akan masuk ke kampung-kampung, kita harus memfilternya. Narkoba sudah meracuni anak-kemenakan kita, penyakit masyarakat telah meluas". (Khairul, 1999:34--35)

Dari kutipan di atas terdapat beberapa simbol. Pertama, seruan untuk kembali ke surau merupakan simbol yang mengandung makna tumbuh kesadaran pada masyarakat kampung untuk menumbuhkan kembali kehidupan beragama. Oleh sebab itu, gubernur menyatakan untuk menghidupkan kembali pengajian-pengajian sebagai pintu gerbang ke arah pemahaman dan pelaksanaan ajaran agama.

Kedua, konsep surau modern merupakan simbol yang mengadung makna Islam tidak melarang dan menghalangi kemajuan ilmu dan teknologi. Bahkan ilmu dan teknologi secara langsung atau tidak langsung dapat menjadi salah satu bukti kebenaran Islam. Contoh, Alquran menyatakan bila semakin mendaki ke langit maka nafas menjadi sesak. Saat ini baru diketahui maksud dari nafas menjadi sesak yaitu akibat kadar oksigen berkurang. Contoh yang lain, Alquran menyatakan proses kejadian manusia di dalam rahim adalah dalam hitungan empat puluh hari. Saat ini baru diketahui memang proses pembentukan manusia adalah dalam hitungan empat pulu hari. Jadi pengertian bid'ah yang dilarang dalam Islam adalah yang menyangkut masalah ibadah bukan mengenai fasilitas ibadah. Islam mempersilahkan orang untuk pergi haji dengan menggunakan pesawat walaupun di zaman Rasulullah menggunakan onta.

Setelah gubernur selesai menyampaikan ide melalui pidato yang disampaikan dengan pengeras suara, gubernur pun pergi. Azan masih belum terdengar dari masjid. Padahal waktu Asyar sudah masuk. Hal itu disebabkan alat pengeras suara masjid dipakai untuk acara pelantikan wali nagari. Hal itu terlihat dalam kutipan berikut.

"Gubernur pun pergi. la pergi dengan
mobil berserine. Bunyi serinenya
meraung-raung mencabik udara. Wali
nagari berpakaian kebesaran serba
putih, disalami warga nagari. Di sisi
jalan, marawa berkibar-kibar disapu
angin. Waktu Asyar telah masuk, tapi
suara azan belum terdengar juga.
Rupanya alat pengeras suara milik
masjid dipakai untuk acara pelantikan
wali nagari". (Khairul, 1999:35)

Azan yang belum terdengar akibat alat pengeras suara dipakai untuk acara pelantikan wali nagari merupakan simbol yang mengandung makna kepentingan terhadap manusia masih lebih diutamakan dibandingkan kepentingan akhirat. Manusia terkadang terlena oleh ajaran yang menyatakan Allah adalah maha pengasih dan maha penyayang. Oleh sebab itu, manusia merasa aman-aman saja bila tidak melakukan penghambaan kepad aAllah SWT sebagaimana mestinya. Manusia lebih mengedepankan "penghambaan" terhadap manusia. Dalam hal ini alat pengeras masjid dipakai untuk pelantikan wali nagari sehingga panggilan azan tidak dapat dikumandangkan. Padahal panggilan azan semestinya lebih utama dibandingkan pelantikan wali nagari.

\section{Penutup}

Berdasarkan analisis semiotik terhadap cerpen Surau karya Khairul Jasmi dapat ditarik beberapa kesimpulan, yaitu 1) surau yang musnah selama 22 tahun merupakan simbol yang bermakna kemunduran kehidupan beragama di kampung Pak Karimun sudah berada dalam taraf yang paling rendah, 2) pengibaratan surau dengan pepaya jantan yang tidak 
berbuah merupakan simbol yang mengandung makna fungsi surau sebagai tempat ibadah dan pembinaan umat tidak berjalan sebagaimana mestinya, 3) pengibaratan surau dengan pepaya jantan yang dapat dijadikan obat yang juga sudah ditinggalkan masyarakat merupakan simbol yang mengandung makna fungsi surau sebagai tempat untuk bermunajat kepada Allah SWT bagi orang-orang yang mencari obat bagi jiwa yang gersang karena terlalu mengejar kehidupan keduniawian dan melupakan akhirat juga sudah mulai ditinggalkan, dan 4) seruan kembali ke surau merupakan simbol yang mengandung makna masih ada sisa-sisa kesadaran pada warga untuk menghidupkan kembali kehidupan keagamaan di kampung tersebut.

\section{Daftar Pustaka}

Jasmi, Khairul. 1999. Buku Kumpulan Cerpen "Surau”. Gramdedia: Jakarta.

Hawwkes. Terence. 1978. Structuralism and Semiotics. London: Methuen \& co. Ltd.

Hill, Knox C. 1966. Interpreting Literature. Chicago: Ihe University Press of Chicago.

Husnan, Ema dkk. 1984. Apresiasi Sastra Indonesia. Bandung: Angkasa.

Pradopo, Rachmat Djoko. 1992. Dewa Telah Mati: Kajian Strukturalisme Semiotik. Makalah yang dibentangkan dalam Temu Ilmiah lmu-ilmu Sastra Pascasarjana se-Indonesia di Bandung pada tanggal 21--22 Oktober 1991. 1993. Pengkajian Puisi. Yogyakarta: Gajah Mada University Press.
Santosa, Djojo. 1991. Kritik Sastra dalam Sastra Jawa Zaman Kemerdekaan. Semarang: Kongres Bahasa Jawa Semarang 15--20 Juli 1991 Prosiding Buku III Pemerintah Provinsi Daerah Tingkat I Jawa Tengah.

Semi. M. Atar. 1988. Anatomi Sastra. Padang Angkasa Raya.

Surana F.X. 1982. Himpunan Materi Seni Sastra. Solo: Tiga Serangkai.

Teww, A. 1982. Sastra Modern. Bandung: Pustaka Jaya.

Tarigan, Henry Guntur. 1988. Prinsipprinsip Dasar Sastra. Bandung: Angkasa.

Zaimar, Okke KS. 1991. Menelusuri Makna Ziarah Karya Iwan Simatupang. Jakarta: Djambatan. 